Diabetologia 10, 661-665 (1974)

(C) by Springer-Verlag 1974

\title{
Evidence for Decreased Sensitivity to Glucose of Isolated Islets from Spiny Mice* (Acomys cahirinus)
}

\author{
A. Gutzeit, A. Rabinovitch**, C. Karakash, W. Stauffacher, A.E. Renold and E. Cerasi*** \\ Department of Medicine, Institute of Clinical Biochemistry and Laboratories for Medical Research, University of \\ Geneva, Geneva, Switzerland
}

Summary. Immunoreactive insulin (IRI) release from collagenase isolated pancreatic islets of spiny mice (Acomys cahirinus) was examined in $15 \mathrm{~min}$ and $2 \mathrm{~h}$ incubations at glucose concentrations between 2.8 and $56 \mathrm{mM}$. The resultant glucose-insulin dose-response curves for Acomys islets were compared to those for similarly incubated rat islets. After 15 min incubations, IRI release from Acomys islets was significantly lower than that from rat islets at all stimulating glucose concentrations. After $2 \mathrm{~h}$ incubations, however, maximal responses were similar for Acomys and rat islets, whereas the sensitivity of Acomys islets to glucose was significantly less. Cyclic AMP $10 \mathrm{mM}$, theophylline $5 \mathrm{mM}$, arginine $10 \mathrm{mM}$, and cytochalasin B $10 \mu \mathrm{g} / \mathrm{ml}$, all enhanced IRI release in the presence of glucose $16.7 \mathrm{mM}$ to a relatively greater extent from Acomys than from rat islets. Vineristine $10^{-5} \mathrm{M}$ reduced IRI release from both Acomys and rat islets, and this to a similar extent. The results suggest that defective IRI release from Acomys islets may be the expression of decreased B-cell sensitivity to ghcose, even though IRI release from Acomys islets may improve in time with continued exposure to elevated glucose concentrations. The ability of B-cells of Acomys to recognize other agents that enhance the action of glucose appeared unaltered.

Key words: Spiny mice (Acomys cahirimus), isolated islets, glucose, theophylline, arginine, cytochalasin $B$, vincristine, insulin release in vitro, sensitivity to glucose.

\section{Introduction}

The pancreas of the rodent Acomys cahirinus of the Geneva colony is characterized histologically by marked hyperplasia of the islets of Langerhans. The immunoreactive insulin (IRI) content of the pancreas is correspondingly elevated $[10,13,23]$. Nevertheless, in vivo studies in the Acomys have demonstrated that IRI response to insulinotropic agents is slower and smaller $[2,3,11]$ than in other rodents. The purpose of the experiments with collagenase isolated islets reported here was to assess whether the low IRI responses observed in vivo could also be demonstrated in vitro.

\section{Materials and Methods}

\section{Animals}

Thirty-one 2-3 month old male Acomys were used. Bred in our laboratory, they were fed ad libitum and weighed 28 to $44 \mathrm{~g}$; at decapitation their plasma glucose was $152 \pm 4 \mathrm{mg} / 100 \mathrm{ml}$. Comparison was with

* This work has been supported by Grants nos. 3.384.70, 3.1060.73 and 3.552.71 of the Fonds National Suisse de la Recherche Scientifique, Berne, Switzerland, and by the Fondation Education et Recherche, Basel, Switzerland.

** Centennial Fellow of the Medical Research Council of Canada.

*** On leave from the Department of Fndocrinology and Metabolism, Karolinska Hospital, Stockholm, Sweden; Visiting Professor at the University of Geneva; recipient of Pfizer Travel Award through the European Association for the Study of Diabetes. male albino Wistar rats, weighing $150-200 \mathrm{~g}$. Their plasma glucose averaged $126 \pm 6 \mathrm{mg} / 100 \mathrm{ml}$.

\section{Experimental Procedures}

Islets were isolated using collagenase according to Lacy et al. [15] either from a single Acomys pancreas, or from pancreata pooled from two rats. 10 islets were placed into each incubation flask, containing $1 \mathrm{ml}$ Krebs-Ringer bicarbonate buffer with bovine serum albumin $5 \mathrm{mg} / \mathrm{ml}$ and Trasylol 500 units $/ \mathrm{ml}$, kindly provided by Dr. H.. Ruef, Bayer Pharma, A.G., Zurich. The flasks were inoubated for $15 \mathrm{~min}$ or for $2 \mathrm{~h}$ in a Dubnoff shaking incubator at $37^{\circ} \mathrm{C}$, and the atmosphere above the open flasks was continuously gassed with $\mathrm{O}_{2} / \mathrm{CO}_{2}: 93 / 7$. Each different condition or agent was tested in at least 5 flasks in a given experiment.

\section{Measurements}

Insulin (IRI) released into the medium was determined by the charcoal separation radioimmunoassay method of Herbert et al. [12]. Islet IRI content was also measured on groups of 10 islets (not incubated) using acid-ethanol extraction ascording to Scott and Fisher [21]. IRI of Acomys was assayed using anti-beef insulin antibody and sheep insulin standard [2] while rat IRI was measured using anti-pork insulin antibody and rat insulin standard. The antibodies were kindly donated by Dr. Peter Wright, Indianapolis, Indiana, and the insulin standards by Dr. J. Schilichtkrull, Novo Industri, Kopenhagen, Denmark. Islet ATP content was assayed by the luciferin-luciferase method of Kilbert et al. [14]. For statistical evaluation Student's unpaired t-test was used. 


\section{Reagents and Chemicals}

Theophylline and arginine hydrochloride were purchased from Merck and Co., Darmstadt, Germany; adenosine $3^{\prime}, 5^{\prime}$-cyclic monophosphate (cyclic AMP), dimethylsulfoxide (DMSO) and perchloric acid from Fluka A.G., Buchs, Switzerland; cytochalasin B from Imperial Chem. Industries, Macclesfield, England; crude collagenase from Worthington Chem., New Jersey; firefly lantern extract from Sigma Chemical Corporation, St. Louis, Missouri; ${ }^{125}$ I-insulin from Cambridge Nuclear, Massachusetts; bovine serum albumin cantly different from that of rat islets $(289 \pm 17 \mathrm{ng} /$ 10 islets, $n=34$ ), although the number of islets isolated from any one Acomys pancreas was approximately double that isolated from any one rat pancreas. The similarity of islet IRI content permitted the use of equal numbers of islets from each species (10 per vial) in the secretion studies described below.

\section{Glucose Dose-Response Studies}

In order to characterize the dose relationships for the early and late IRI responses, islets were incubated

$15 \mathrm{~min}$.

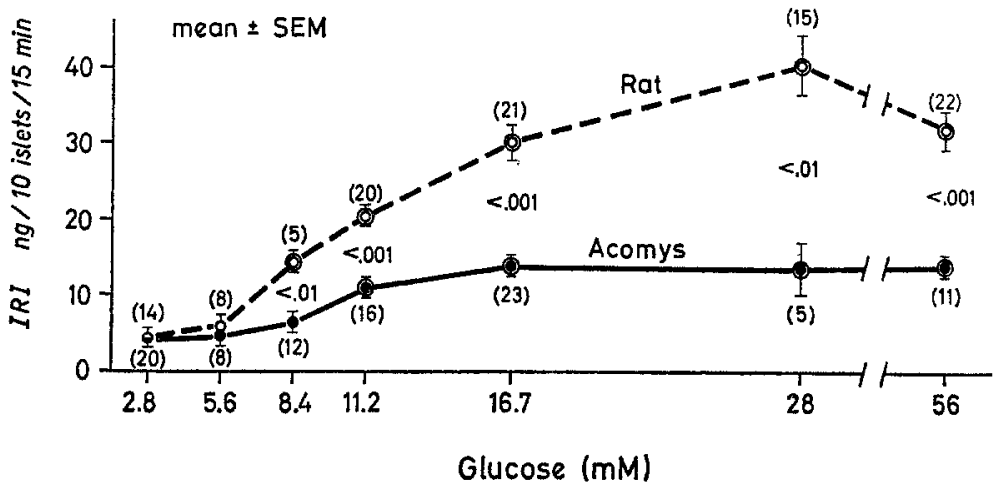

Fig. 1. Glucose-insulin (IRI) dose-response curves from rat [0-_-o] and Acomys [0-0] islets incubated for $15 \mathrm{~min}$. The p-values between the two curves indicate the degree of statistical difference between IRI release for the two species at corresponding glucose concentrations. IIRI release values significantly $(p<0.05)$ higher than those at glucose $2.8 \mathrm{mM}$ are indicated as 0 or as - Numbers in parentheses denote the number of experiments

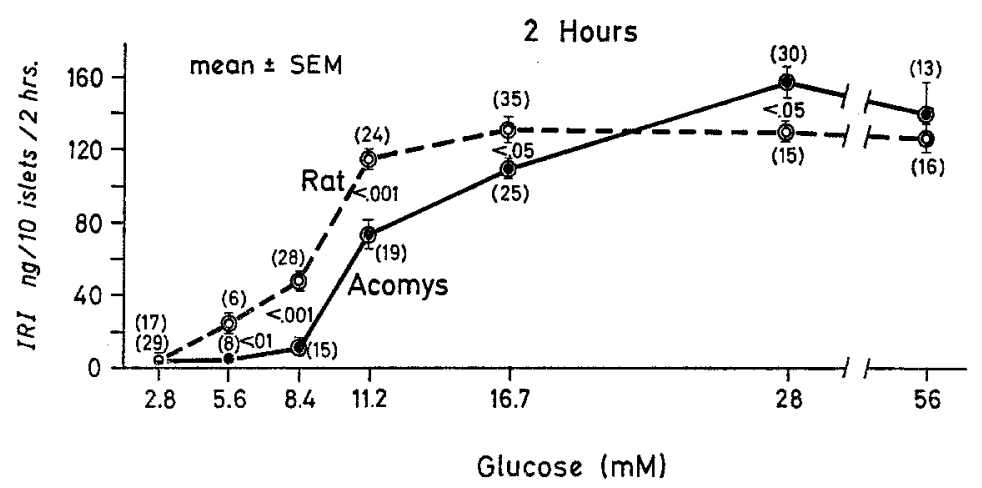

Fig. 2. Glucose-insulin (IRI) dose-response curves from islets incubated for $2 \mathrm{~h}$. Data are presented as in Fig. 1. Note the smaller scale for IRI release

(fraction V), from Behringwerke, Marburg, Germany. Vincristine sulfate, lot NDC 2-N55-A (Oncovin, Eli Lilly), was a gift from Schweiz. Serum- und Impfinstitut, Bern, Switzerland.

\section{Results}

\section{Insulin Content of the Islets}

The acid-ethanol extractable IRI content of $A$ comys islets ( $299 \pm 10 \mathrm{ng} / 10$ islets, $n=88$ ) was not signifi- in the presence of different concentrations of glucose, either for $15 \mathrm{~min}$ (reflecting mainly the early response) or for $2 \mathrm{~h}$ (mainly the late response). Fig. 1 shows the glucose-IRI dose-response curves during the $15 \mathrm{~min}$ incubations for each species. The lowest glucose concentration which resulted in significant stimulation of IRI release above basal levels was $11.2 \mathrm{mM}$ for Acomys islets ( $p<0.05$ vs. basal release), and $8.4 \mathrm{mM}$ for rat islets $(p<0.01)$. For both species the plateau of maximal release was reached at $16.7 \mathrm{mM}$ (the higher levels noted at $28.0 \mathrm{mM}$ glucose for rat islets were not signifi- 


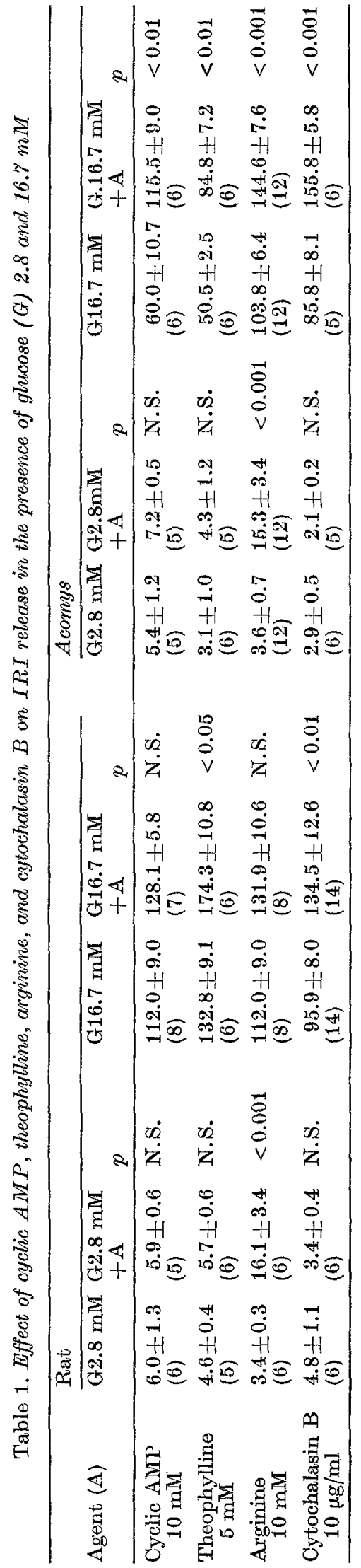

cantly different from the values at 16.7 or $56.0 \mathrm{mM}$ ). Also, the glucose concentration inducing half-maximal insulin release was similar in both species (around $10 \mathrm{mM})$. Thus, during a short incubation (15 min), Acomys islets exhibited a higher threshold for glucose and significantly lower rates of insulin release at all stimulating glucose levels by comparison with rat islets $(p<0.01)$.

The insulin release responses observed during $2 \mathrm{~h}$ of incubation are shown in Fig. 2. Again, the threshold glucose concentration eliciting IRI release above basal levels was higher for Acomys islets ( $8.4 \mathrm{mM}, p<0.05$ $v s$. basal release) than for rat islets ( $5.6 \mathrm{mM}, p<0.01)$. The maximal IRI response of Acomys islets to glucose, however, was similar to that of rat islets, although this maximal response was observed at $28 \mathrm{mM}$ glucose for Acomys, as compared to $16.7 \mathrm{mM}$ for rat islets. Halfmaximal response was seen at about $12.0 \mathrm{mM}$ glucose for Acomys islets and $9.5 \mathrm{mM}$ for rat islets. Thus, over $2 \mathrm{~h}$ of incubation, the glucose-IRI dose, response curve for Acomys islets was shifted to the right of that for rat islets, still indicating a decreased sensitivity of the Acomys islets to glucose, even though the maximal response reached did not differ from that of rat islets.

\section{Enhancement of the Late Insulin Response by Agents Other than Glucose}

The effect of some agents known to enhance the insulin response to glucose was evaluated in islets incubated for $2 \mathrm{~h}$ in the presence of either low $(2.8 \mathrm{mM})$ or high $(16.7 \mathrm{mM})$ glucose (Table 1). The islets used for comparison between different experimental conditions were obtained from the same collagenase isolation batch. Cyclic AMP (10 mM) did not modify the response to glucose $2.8 \mathrm{mM}$ in either species, nor did it significantly increase the IRI response to glucose $16.7 \mathrm{mM}$ in rat islets $(+14 \%$, NS). However, it augmented significantly the IRI release at high glucose concentration in Acomys islets $(+90 \%, p<0.01)$. Theophylline $5 \mathrm{mM}$, an agent that raises the intracellular concentration of cyclic AMP [1], had no effect on IRI release at glucose $2.8 \mathrm{mM}$, but enhanced the IRI secretion at glucose $16.7 \mathrm{mM}$ in both species, the effect being greater in Acomys islets $(+68 \%, p<0.01)$ than in rat islets $(+31 \%, p<0.05)$. Arginine $10 \mathrm{mM}$ had similar pronounced effects on IRI release at glucose $2.8 \mathrm{mM}$ in both species $(+300 \%, p<0.001)$. In the presence of glucose $16.7 \mathrm{mM}$ it stimulated Acomys islets $(+39 \%$, $p<0.001)$ to a greater extent than rat islets $(+18 \%$, NS). Cytochalasin B, an agent known to affect the microfilamentous system and to enhance glucose-induced IRI release [17, 24] had no effect on basal IRI release, but augmented the response to high glucose in both species. Again, the effect was greater in Acomys islets $(+82 \%, p<0.001)$ than in rat islets $(+40 \%$, $p<0.01$ ).

\section{Effects of Vincristine}

(Fig. 3). All incubations were carried out at glucose $16.7 \mathrm{mM}$ for $2 \mathrm{~h}$. Vincristine, at the concentration of 
$10^{-5} \mathrm{M}$, slightly but significantly reduced the stimulating effect of glucose $16.7 \mathrm{mM}$ on IRI release by islets of both species $(-25$ to $-30 \%, p<0.05)$. Increasing the concentration to $10^{-4} \mathrm{M}$ did not reduce IRI release any further, but significantly decreased islet ATP levels, again in both species $(-25$ to $-30 \%, p<0.01)$.

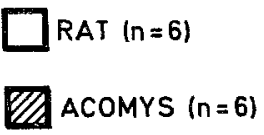

IRI Release

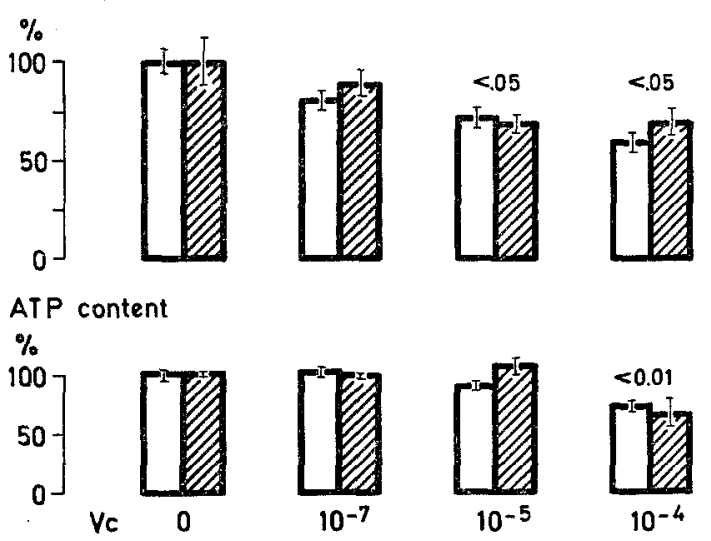

Fig. 3. IRI release (upper panel) and intracellular ATP levels (lower panel) from rat and acomys islets incubated for $2 \mathrm{hrs}$ in the presence of glucose $16.7 \mathrm{mM}$. The Vincristine $(\mathrm{Vc})$ concentrations varied between 0 and $10^{-4} \mathrm{M}$. Values above bars indicate significant differences from control (absence of Vincristine, set as 100\%) for both species

\section{Discussion}

The results presented in this report show clearly that the low insulin responses observed in vivo in Acomys $[2,3,11]$ are also to be seen in vitro. This decreased responsiveness is thus not likely to be due to modifications in the metabolism of the hormone but may well be a characteristic of the pancreatic B-cells of Acomys. Whether the choice of the rat as the control animal was appropriate or not is, of course, open to question. However, since the islets of these two species contain similar amounts of insulin, in spite of the marked differences in body size of their hosts, this comparison appears justified.

The striking finding in this comparison is the difference between the two species in their respective glucose-insulin dose response relationship. Both regarding the early $(15 \mathrm{~min})$ and prolonged $(2 \mathrm{~h})$ insulin responses, sensitivity of the Acomys islet was less, as evidenced by the higher glucose "threshold" values needed to induce stimulation of insulin release. By contrast, whereas the maximal Acomys response at 15 min was much smaller than that of rat islets, after $2 \mathrm{~h}$ the islets of both species reached comparable maximal rates of release (albeit at different glucose levels). Thus, in the present in vitro system, while both the early and the late phase insulin responses of Acomys islets exhibited decreased sensitivity to glucose (as compared to the sensitivity of rat islets), decreased capacity (i.e. a low maximal response) was observed only for the early insulin release phase.

Observations in man [8] may suggest an explanation for the augmentation in maximal response seen during prolonged incubation of Acomys islets with glucose. It was shown that glucose, with time, enhances markedly its own effect on insulin release. Applying these concepts to the insulin response of Acomys, the data available support the hypothesis of impaired ability to recognize glucose as an initiating signal, while recognition of the time-related enhancing action of the sugar may be intact. Support for this interpretation derives from the observation that all agents which have been tested because of their known enhancing action on glucose-induced IRI release were effective in islets of Acomys, indeed more effective than was true for islets from rats, when considering the prolonged (two hours) incubations. The agents tested were cyclic AMP, theophylline, arginine and cytochalasin B. The point to be emphasized here is the presence of at least normal enhancement by agents other than glucose, not the still tentative demonstration of a greater than normal one. Before accepting the latter observation the comparison with rat islets will have to be carried out under a range of different experimental conditions, since the present one may not be optimal for the demonstration of enhancement in islets from rats. It may nevertheless be concluded that Acomys islets do not show impairment in the recognition of agents which modulate the effects of glucose.

The cause of the lower insulin release from the Bcells of Acomys in response to glucose remains obscure. Several possibilities have been discussed previously [20] one of them being that suggested by MalaisseLagae et al. [18] who demonstrated that the number of Vincristine-induced crystals was much less in Acomys B-cells than in those of other rodents. A possible interpretation of that observation is that a deficiency of the microtubular system might be involved in producing the characteristic insulin release pattern of Acomys. The results reported here with vincristine neither support nor invalidate this view, as sensitivity of insulin release to vincristine was similar in Acomys and rat islets; toxic effects of the drugs, in terms of decrease in ATP, also occurred at equal concentrations in both species, thereby suggesting that the penetration of vincristine across the B-cell membrane was not altered.

In closing, a brief discussion of purely speculative nature may be in order. The insulin release pattern observed in Acomys appears to resemble that observed at various stages of the diabetic syndrome in man $[4$, $19,22]$. Decreased insulin response to glucose administration, much more marked for the initial response phase, is frequently found in subjects with latent or 
chemical diabetes as well as in patients with maturityonset diabetes. The same pattern, and again it is the pattern seen in Acomys as well, has been described in a number of subjects with entirely normal glucose tolerance in whom, however, the probability to develop diabetes at a later stage is greater than for the general population [7]. In the studies referred to in man, decreased sensitivity to ghucose in terms of insulin release, as in the present study, was demonstrated [6]. Furthermore, the enhancing effect of agents such as theophylline [5] or arginine [9] was either intact or augmented in the subjects exhibiting a decreased insulin response to glucose alone. Despite all the qualifications which must be kept in mind before information obtained in one species may be transferred to another, the results described in this report clearly encourage us in continued attempts to analyze Acomys as completely as possible, as one possible model for some aspects of diabetes-relatedendocrine function.

Acknowledgements. We acknowledge gratefully the expert technical assistance of Mrs. Savina Kalfopoulos and Mrs. Liza Cavillier; also the outstanding animal care of Mr. Raymond Cuche.

\section{References}

1. Brisson, G.R., Malaisse-Lagae, F., Malaisse, W.J. The stimulus-secretion coupling of glucose-induced insulin release; VII: A proposed site of action for adenosine $3^{\prime}, 5^{\prime}$-cyclic monophosphate. J. clin. Invest. $\mathbf{5 1}, 232-241(1972)$

2. Cameron, D.P., Stauffacher, W., Orci, L., Amherdt, M., Renold, A.E.: Defective immunoreactive insulin secretion in the Acomys cahirinus. Diabetes 21, 1060 $1071(1972)$

3. Cameron, D.P., Stauffacher, W., Amherdt, M., Orci, L., Renold, A.E. : Kinetics of immunoreactive insulin release in obese hyperglycemic laboratory rodents. Endocrinology 92, 257-264 (1973)

4. Cerasi, E., Luft, R. : Plasma insulin response to glucose infusion in healthy subjects and in diabetes mellitus. Acta endocr. (Kbh.) 55, 278-304 (1967)

5. Cerasi, E., Luft, R.: The effect of an adenosine $3^{\prime}-5^{\prime}$ monophosphate diesterase inhibitor (Aminophylline) on the insulin response to glucose infusion in prediabetic and diabetic subjects. Horm. Metab. Res. 1, $162-168(1969)$

6. Cerasi, E., Luft, R., Efendic, S.: Decreased sensitivity of the pancreatic beta cells to glucose in prediabetic and diabetic subjects. A glucose dose-response study. Diabetes 21, 224-234 (1972)

7. Cerasi, E., Luft, R.: Follow-up of non-diabotic subjects with normal and decreased insulin response to glucose infusion - First report. Horm. Metab. Res. (In press)

8. Cerasi, E.: Potentiation of insulin release by glucose in man (I, II and III). (Submitted)

9. Efendic, S., Cerasi, E., Luft, R.: Quantitative study on the potentiating effect of arginine on glucoseinduced insulin response in healthy, prediabetic, and diabetic subjects. Diabetes 23, 161-171 (1974)

10. Gonet, A. E., Stauffacher, W., Pictet, R., Mougin, J., Renold, A.E.: Obesity and diabetes mellitus with striking congenital hyperplasia of the islets of Langerhans in spiny mice (Acomys cahirinus). Diabetologia $1,162-171(1965)$
11. Gutzeit, A., Rabinovitch, A., Studer, P.P., Trueheart, P.A., Cerasi, E., Renold, A. E.: Decreased intravenous glucose tolerance and low plasma insulin response in spiny mice (Acomys cahirinus). Diabetologia 10, $667-670(1974)$

12. Herbert, V., Lau, K. S., Gottlieb, C.W., Bleicher, S.J.: Coated charcoal immunoassay of insulin. J. clin. Endocr. 25, 1375-1384 (1965)

13. Junod, A., Letarte, J., Lambert, A.E., Stauffacher, W.: Studies in spiny mice (Acomys cahirinus): metabolic state and pancreatic insulin release in vitro. Horm. Metab. Res. 1, 45-52 (1969)

14. Kilbert, Jr., L.H., Schiff, M.S., Foa, P.P.: The measurement of ATP in pancreatic islets by means of the Luciferin-Luciferase reaction. Horm. Metab. Res. 4, $242-244$ (1972)

15. Lacy, P.E., Young, D.A., Fink, C.J.: Studies on insulin secretion in vitro from isolated islets of the rat pancreas. Endocrinology 83, 1155-1161 (1968)

16. Lambert, A.E., Jeanrenaud, B., Junod, A., Renold, A.E.: Organ culture of fetal rat pancreas. II. Insulin release induced by amino and organic acids, by hormonal peptides, by cationic alterations of the medium and by other agents. Biochim. biophys. Acta. (Amst.) 184, 540-553 (1969)

17. Malaisse, W.J., Hager, D.L., Orei, L.: The stimulussecretion coupling of glucose-induced insulin release. IX. The participation of the beta cell web. Diabetes 21, 594-604 (1972)

18. Malaisse-Lagae, F., Ravazzola, M., Amherdt, M. Gutzeit, A., Malaisse, W.J., Orci, L.: An apparent abnormality of the B-cell microtubular system in spiny mice (Acomys cahirinus) (in press)

19. Perley, M.J., Kipnis, D.M.: Plasma insulin responses to glucose and tolbutamide of normal-weight and obese diabetic and non-diabetic subjects. Diabetes 15, $867-874(1966)$

20. Renold, A.E., Rabinovitch, A., Wollheim, C.B., Kikuchi, M., Gutzeit, A.H., Amherdt, M., MalaisseLagae, F., Orci, L.: Spontaneous and experimental diabetic syndromes in animals. A re-evaluation of their usefulness for approaching the physiophathology of diabetes. Excerpta Medica Int. Congr. Series No. 312, Diabetes, Malaisse, W.J., Pirart, J. (eds.) Proc. 8th Congr. Internal. Diab. Fed. Amsterdam: Excerpta Medica Found. 1973

21. Scott, D.A., Fisher, A.M.: The insulin and zinc content of normal and diabetic pancreas. $J$. clin. Invest. 17, $725-728$ (1938)

22. Seltzer, H.S., Allen, E.W., Herron, Jr., A., Brennan, M.T.: Insulin secretion in response to glycemic stimulus: Relation of delayed initial release to carbohydrate intolerance in mild diabetes mellitus. J. clin. Invest. 46, 323-335 (1967)

23. Stauffacher, W., Orci, L., Amherdt, M., Burr, I.M., Balant, L., Froesch, E.R., Ronold, A.E.: Metabolic state, pancreatic insulin content and B-cell morphology of normoglyeemic spiny mice (Acomys cahirinus): Indications for an impairment of insulin secretion. Diabetologia 6, 330-342 (1970)

24. Van Obberghen, E., Somers, G., Devis, G., Vaughan, G.D., Malaisse-Lagae, F., Orci, L., Malaisse, W.J.: Dynamics of insulin release and microtubular microfilamentous system. I. Effect of cytochalasin B. J. clin. Invest. 52, 1041-1051 (1973)

Dr. A. Gutzeit

Department of Medicine

Institute of Clinical Biochemistry

University of Geneva

CH-1211 Geneva 4

Switzerland 